\title{
Cellulase and Macerozyme-PEG-mediated Transformation of Moss Protoplasts
}

Batth, Rituraj; Cuciurean, Ilenuta Simina; Kodiripaka, Satish Kumar; Rothman, Sarah Skovlund; Greisen, Caroline; Simonsen, Henrik Toft

\section{Published in:}

Bio-protocol

Link to article, DOI:

10.21769/BioProtoc.3782

Publication date:

2021

Document Version

Publisher's PDF, also known as Version of record

Link back to DTU Orbit

Citation (APA):

Batth, R., Cuciurean, I. S., Kodiripaka, S. K., Rothman, S. S., Greisen, C., \& Simonsen, H. T. (2021). Cellulase and Macerozyme-PEG-mediated Transformation of Moss Protoplasts. Bio-protocol, 11(2), [e3782].

https://doi.org/10.21769/BioProtoc.3782

\section{General rights}

Copyright and moral rights for the publications made accessible in the public portal are retained by the authors and/or other copyright owners and it is a condition of accessing publications that users recognise and abide by the legal requirements associated with these rights.

- Users may download and print one copy of any publication from the public portal for the purpose of private study or research.

- You may not further distribute the material or use it for any profit-making activity or commercial gain

- You may freely distribute the URL identifying the publication in the public portal 


\section{Cellulase and Macerozyme-PEG-mediated Transformation of Moss Protoplasts}

Rituraj Batth, Ilenuta Simina Cuciurean, Satish Kumar Kodiripaka, Sarah Skovlund Rothman, Caroline Greisen and Henrik Toft Simonsen*

Department of Biotechnology and Biomedicine, Technical University of Denmark, Kongens Lyngby, 2800 Denmark

*For correspondence: hets@dtu.dk

[Abstract] This protocol describes the generation of protoplasts from protonemal tissue of the moss Physcomitrium patens (syn. Physcomitrella patens), using Cellulase ONOZUKA R10 and Macerozyme R10, followed by polyethylene glycol (PEG) mediated transformation. The protonemal tissue grown in liquid suspension was harvested and treated with enzyme cocktails mix of $1.5 \%$ Cellulase ONOZUKA R10 and 0.5\% Macerozyme R10 to generate 1,8 million protoplasts within $3 \mathrm{~h}$.

Keywords: Moss, Physcomitrium patens (syn. Physcomitrella patens), Protoplastation, Cellulase, Macerozyme

[Background] Thanks to its efficiency in the natural homology directed repair Physcomitrium patens is ideal to use as a plant experimental system, especially for heterologous expression of genes, permitting the generation of transformants with predictable properties and characteristics. Moreover, P. patens has the advantage of low-cost cultivation and it can be maintained in large quantities in bioreactors (Reski et al., 2018). The genetic engineering of $P$. patens cells allows the large-scale production of natural products and drugs such as thapsigargin and other terpenoid drug candidates, which are difficult of access (Simonsen et al., 2009). This protocol shows how to isolate and transform $P$. patens protoplasts released from the haploid protonema filaments. $P$. patens has been already used for generation and PEG-mediated transformation of protoplasts. In the previous experiments protoplastation on $P$. patens is performed with the enzyme Driselase from Basidiomycetes (Cove et al., 2009; Bach et al., 2014). With the model plant Arabidopsis thaliana, 60 min of incubation with constant shaking in darkness allows one to obtain a consistent amount of viable protoplasts (Fesenko et al., 2016). Although the Physcomitrium tissue digestion fulfilled by Driselase is highly efficient and fast (Bach et al., 2014; King et al., 2016), the instable delivery and availability of Driselase led to the study of a different procedure for protoplastation and to look for more widely used enzymes. Here we describe an alternative efficient method, using the enzyme Cellulase ONOZUKA R-10 in combination with Macerozyme R-10. Cellulases and pectinases have been successfully tested on different plants such as Fritillaria imperialis L. (Chamani and Tahami, 2016), Penium margaritaceum (Raimundo et al., 2018), Ananas comosus L. (Priyadarshani et al., 2018), Brassica oleracea L. and Brassica napus L. (Kaur et al., 2018) and it is regularly used on Arabidopsis thaliana (Abel and Theologis, 1994; Yoo et al., 2007), but to our knowledge it has not been published on $P$. patens. Additionally, in this protocol the incubation is performed without shaking. Further modifications of the experimental conditions could possibly optimize 
the protocol even more to yield more protoplasts.

\section{Materials and Reagents}

1. Falcon $^{\mathrm{TM}}$ (Size $50 \mathrm{ml}$; D-51588)

2. Cell strainers (70 $\mu \mathrm{m}$ nylon mesh, Fischer brand, catalog number: 22363548)

3. Cell strainers ( $40 \mu \mathrm{m}$ nylon mesh, Fischer brand, catalog number: 22363547)

4. Round bottomed glass tube with screw cap (size: $11 \mathrm{ml}$; Pyrex, catalog number: 10004654)

5. Scalpel blade (Thermo Scientific ${ }^{\mathrm{TM}} 53221$, catalog number: 12657776 )

6. Petri-dishes (Fisherbrand ${ }^{\mathrm{TM}}$ Polystyrene Petri Dishes, Sterile; size: $90 \mathrm{~mm}$ )

7. Syringe filter $(0.45 \mu \mathrm{m}$, FRISENETTE, catalog number: CALS2504100S)

8. Sterile syringe (20 ml and $50 \mathrm{ml}$ ) (Chirana, catalog numbers: $\mathrm{CH} 03020 \mathrm{~L} ; \mathrm{CH} 03050 \mathrm{~L}$ )

9. Sterile pipette tips (Labsolute, non-pyrogenic, single use, size: $50 \mathrm{ml}, 10 \mathrm{ml}, 5 \mathrm{ml}$ )

10. Moss (Physcomitrella patents) that is blended 4-5 days in advance (liquid culture) and grown at $16 \mathrm{~h}$ light/ $8 \mathrm{~h}$ dark cycle at $25{ }^{\circ} \mathrm{C}$ in presence of $5 \mathrm{mM}$ of Ammonium Tartrate as described previously in Bach et al. (2014).

11. Cellulase ONOZUKA R-10 1.5\% (w/v) (DUCHEFA, catalog number: C8001.0010, CAS No: 9012-54-8), storage temperature $2-8{ }^{\circ} \mathrm{C}$

12. Macerozyme R-10 0.5\% (w/v) (DUCHEFA, catalog number: M8002.0010, CAS No: 9032-75-1), storage temperature $2-8{ }^{\circ} \mathrm{C}$

13. D-Mannitol (Duchefa Biochemie, catalog number: M0803.5000; CAS No: 69-65-8)

14. $\mathrm{CaCl}_{2}$ (SIGMA, catalog number: C3306-550G; CAS number: 10035-04-8)

15. MES hydrate (SIGMA, catalog number: M2933-1Kg)

16. $\mathrm{KOH}$ (SIGMA, catalog number: 484016-1KG; CAS No: 1310-58-3)

17. Trizma base (SIGMA, catalog number: T6066-1Kg; CAS no: 77-86-1)

18. $\mathrm{HCl}$ (VWR Chemicals, catalog number: 20255.200; CAS no: 7647-01-0)

19. $\mathrm{Ca}\left(\mathrm{NO}_{3}\right)_{2} \cdot 4 \mathrm{H}_{2} \mathrm{O}$ (SIGMA, catalog number: $\mathrm{C} 2788-500 \mathrm{G}$; CAS no: 13477-34-4)

20. Polyethylene glycol (PEG, MW 6000) (SIGMA, catalog number: 81253-250G; CAS no: 2532268-3)

21. $\mathrm{MgCl}_{2}$ (SIGMA, catalog number: M8266; CAS no: $7786-30-3$ )

22. Agar, plant cell culture tested (Alfa Aesar, catalog number: H26724; CAS no: 9002-18-0)

23. Ammonium tartrate (SIGMA, catalog number: 09985-250G; CAS No: 3164-29-2)

24. $\mathrm{H}_{3} \mathrm{BO}_{3}$

25. $\mathrm{MnCl}_{2} \cdot 4 \mathrm{H}_{2} \mathrm{O}$

26. $\mathrm{AIK}\left(\mathrm{SO}_{4}\right)_{2} \cdot 12 \mathrm{H}_{2} \mathrm{O}$

27. $\mathrm{CoCl}_{2} \cdot 6 \mathrm{H}_{2} \mathrm{O}$

28. $\mathrm{CuSO}_{4} \cdot 5 \mathrm{H}_{2} \mathrm{O}$

29. $\mathrm{ZnSO}_{4} \cdot 7 \mathrm{H}_{2} \mathrm{O}$

30. $\mathrm{KBr}$ 
31. $\mathrm{KI}$

32. $\mathrm{LiCl}$

33. $\mathrm{SnCl}_{2} \cdot 2 \mathrm{H}_{2} \mathrm{O}$

34. $8.5 \%$ Mannitol (see Recipes)

35. $1 \mathrm{M} \mathrm{CaCl}_{2}$ (see Recipes)

36. $2 \mathrm{M} \mathrm{KOH}$ (see Recipes)

37. 0.2 M MES pH 5.8 (see Recipes)

38. Protoplast media (PM) (see Recipes)

39. Protoplast wash solution (PW) (see Recipes)

40. $0.4 \mathrm{M}$ Tris-Cl pH 8.0 (see Recipes)

41. PEG-MCT (see Recipes)

42. $1 \mathrm{M} \mathrm{MgCl}_{2}$ (see Recipes)

43. MMM solution (see Recipes)

44. PRMB media (see Recipes)

45. PRMT media (see Recipes)

46. BCD Media (see Recipes)

47. BCD Plate (see Recipes)

48. $500 \mathrm{mM}$ Ammonium tartrate (see Recipes)

\section{Equipment}

1. Flasks, Erlenmeyer (1 L, sterile)

2. Reagent bottles $(500 \mathrm{ml}, 250 \mathrm{ml}, 100 \mathrm{ml})$

3. Serological pipette (Brand ${ }^{\circledR}$ Accu-jet ${ }^{\circledR}$ pro, catalog number: 19B17038)

4. Centrifuge (ThermoFisher, model: Heraeus ${ }^{\mathrm{TM}}$ Multifuge $^{\mathrm{TM}} \mathrm{X} 1 \mathrm{R}$ )

5. Haemocytometer (Neubauer-improved $0.1 \mathrm{~mm}$, Superior MARIENFELD Germany; catalog number: 0650030)

6. Light microscope (OLYMPUS, BX40)

7. $30^{\circ} \mathrm{C}$ incubator (Gerhardt Thermoshake)

8. Scalpel handle (Thermo Scientific ${ }^{\mathrm{TM}} 53410$, catalog number: 12667776)

9. Forceps (Bochem ${ }^{\mathrm{TM}}$ 1020R, catalog number: 10333511)

10. Microwave (Whirlpool, GUSTO: GT285)

11. Sterile cellophane disks (Size: 80 mm, Company: Focus Packaging \& Design Ltd, PKS150 $70-$ 01, Batch: 05377)

12. Surgical tape (Micropore, $1,25 \mathrm{~cm} \times 9.1 \mathrm{~m}, 1 / 2 \mathrm{in} \times 10 \mathrm{yd}$, Ref: $1530-0$ )

13. Bunsen burner (Campingaz, Easy clic $^{\text {TM }}$ Plus; CV300 Plus)

14. Laminar Air Flow Bench (LAF Bench)

15. Water bath at $45^{\circ} \mathrm{C}(\mathrm{MgW}$ LAUDA MS)

16. Rocker (Brand: Desaga, Starstedt-Gruppe) 
17. Homogeniser (IKA ${ }^{\circledR}$ T25 digital ULTRA TURRAX)

\section{Procedure}

\section{Procedural guidelines}

Notes:

1. Perform all steps at room temperature $\left(20-25^{\circ} \mathrm{C}\right)$ unless noted otherwise.

2. Use solutions and equipment sterilized by autoclavation or filter sterilization.

3. Always use microbiological aseptic techniques and work in a sterile facility when handling moss.

4. Perform all centrifugation steps at $200 \times \mathrm{g}$ with slow acceleration and breaking speeds* unless noted otherwise.

${ }^{*}$ Acceleration speed 2 and deceleration speed 4 when using the Heraeus $^{T M}$ Multifuge $^{T M}$ X1R (Thermo Fisher).

\section{Protoplasts generation}

A. Moss preparation

Note: Blend the moss twice before use, with at least 7 days gap between each blend. Add $5 \mathrm{mM}$ of ammonium tartrate to grow the moss. After the second blend, use the moss on either $4^{\text {th }}$ or $5^{\text {th }}$ day for transformation.

1. Filter 5-day old protonemal moss tissue by straining through $70 \mu \mathrm{m}$ cell strainer.

2. Place the cell strainer on a $50 \mathrm{ml}$ Falcon tube. Filter $40 \mathrm{ml}$ of moss culture through the strainer to collect the moss on top (Figure 1). Transfer the cell strainer onto a new Falcon tube and repeat the filtration step multiple times to collect $\sim 1.5 \mathrm{~g}$ of moss.

3. Transfer the cell strainer with collected moss on a fresh $50 \mathrm{ml}$ Falcon tube. Pass $50 \mathrm{ml}$ of autoclaved demineralized water through the strainer to wash and remove the traces of $B C D$ media from the moss. Repeat this washing step 4-5 times.

4. Split the collected moss from the strainer into five $50 \mathrm{ml}$ Falcon tubes using a sterile forcep. Each tube should contain approximately 200 to $300 \mathrm{mg}$ of vegetal tissue. 
A

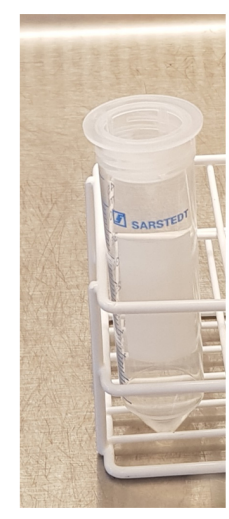

B

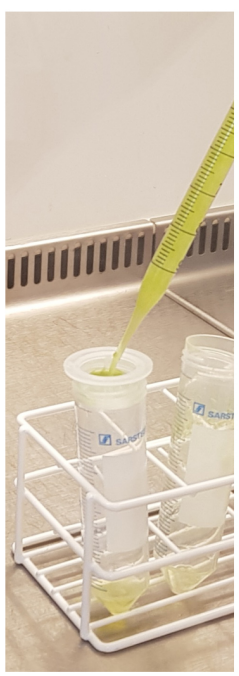

Figure 1. Collection of moss protonemal tissue for protoplastation. A. Sterile $70 \mu \mathrm{m}$ cell strainer placed on a Falcon tube. B. Passing moss culture through the strainer to collect the moss on top.

B. Enzyme solution (prepare fresh)

1. Prepare enzyme solution in a glass beaker by adding $750 \mathrm{mg}$ of Cellulase Onozuka R-10 to 50 $\mathrm{ml}$ of PM media. Stir using magnetic bead to dissolve the salt, until the solution looks clear.

2. Once the Cellulase completely dissolves, add $250 \mathrm{mg}$ of Macerozyme R-10 and dissolve completely as before.

Note: The systematic addition of both salts ensures their complete dissolution. The enzyme solution at this point should have a light brown color.

3. Transfer the enzyme solution to a $50 \mathrm{ml}$ Falcon tube and centrifuge at $5,000 \mathrm{~g}$ for $2 \mathrm{~min}$ (set the acceleration and deceleration speed pf centrifuge to 9).

4. Avoid the pellet and filter sterilize the supernatant by using $0.45 \mu \mathrm{m}$ syringe filter into a new 50 $\mathrm{ml}$ Falcon tube, inside the LAF bench.

5. Divide $10 \mathrm{ml}$ of sterile enzyme solution to five Falcon tubes containing moss (from Step A4), shake to suspend and transfer the mixture to five sterile Petri-dishes.

6. Incubate the protonemal tissue in the enzyme solution for at least $3 \mathrm{~h}$ at $30^{\circ} \mathrm{C}$ in dark. After 1.5 $\mathrm{h}$, microscopically assess the number of free-floating protoplasts in a drop of digested solution, followed by assessing after every $30 \mathrm{~min}$. Proceed when most of the protonemal tissue has been digested.

IMPORTANT! Moss protoplasts are very fragile and can easily be damaged by disturbances. When handling protoplasts, proceed with extreme caution and avoid physical disruption. Use pipette tips with a wide opening (cut the tip of regular pipette tips with a heated sterile scalpel) and draw up protoplast suspensions slowly to avoid disruption caused by suction. Never vortex protoplast suspensions. Perform all steps under sterile conditions inside a LAF Bench. 
C. Isolate protoplasts

1. Recover the protoplasts by filtering the suspension through a $70 \mu \mathrm{m}$ cell strainer. Wash the Petri-dishes with 2-3 $\mathrm{ml}$ of PM to dissolve any leftover moss sticking to the surface, and filter this as well through the mesh, to collect all protoplasts.

2. Again, pass the digested solution through $40 \mu \mathrm{m}$ mesh to further remove cell debris and undigested protonema.

3. Collect the filtrate in $50 \mathrm{ml}$ Falcon tubes and distribute to five $10 \mathrm{ml}$ round bottomed glass tubes. Note: Use additional glass tube with $10 \mathrm{ml}$ water to balance while centrifugation.

4. Centrifuge the protoplast suspension for $10 \mathrm{~min}$ at $200 \times \mathrm{g}, 22{ }^{\circ} \mathrm{C}$.

5. Carefully decant the supernatant using a pipette rather than inverting the tube. This avoids the risk of losing the pellet as protoplasts pellet is not tightly adhered to walls of tube. While pipetting leave behind small volume of supernatant so that the protoplast pellet remains immersed.

6. Resuspend the protoplast pellet in approximately $1 \mathrm{ml} \mathrm{PW}$ solution by gently shaking the tube. Collect the protoplast suspensions from all tubes into one and add PW to obtain a total volume of $10 \mathrm{ml}$.

7. Repeat Steps $\mathrm{C} 4$ and $\mathrm{C} 5$.

8. Resuspend the protoplast pellet in $3 \mathrm{ml} \mathrm{PW}$ solution by gently shaking the tube. Estimate the protoplast density with a Haemocytometer. Count the number of protoplasts on both grid areas (see Figure 2 for an image of protoplasts) and use the average to estimate the number of protoplasts.

TOTAL VOLUME OF THE GRID AREA ON THE HEMOCYTOMETER:

$1 \mathrm{~mm} \times 1 \mathrm{~mm} \times 0.1 \mathrm{~mm}=0.1 \mathrm{~mm}^{3}$

ESTIMATED NUMBER OF PROTOPLASTS IN THE SOLUTION:

Protoplasts on grid area $\times 10^{4} \times$ total volume in $\mathrm{ml}=$ number of protoplasts

9. Repeat Step C4.

10. Carefully decant most of the supernatant using a pipette and stop pipetting when the pellet starts to dissolve.

11. Resuspend the protoplast pellet in required amount of MMM solution to obtain a final concentration of $1.6 \times 10^{6}$ protoplasts $/ \mathrm{ml}$.

FINAL VOLUME MMM-PROTOPLASTS SUSPENTION:

$\frac{\text { number of protoplasts }}{1.6 \times 10^{6}}=$ final volume in $\mathrm{mL}$ 

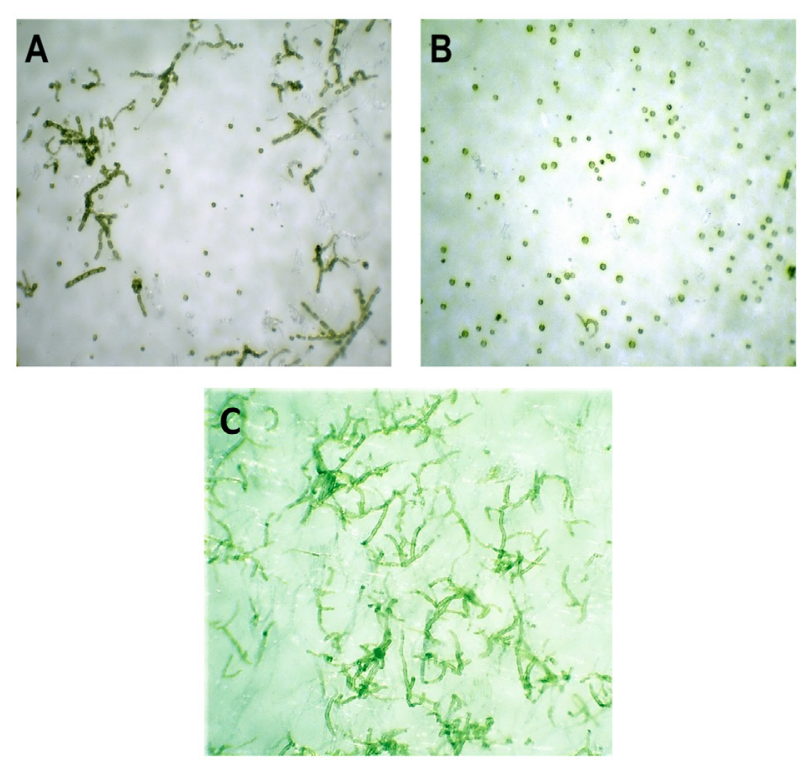

Figure 2. The figure show microscope images of protoplasts from $P$. patens. A. This is some free protoplast and with protonemal tissue. B. Only free protoplast. B is the ideal situation after the treatment. C. Undigested protonema tissue.

D. Protoplast transformation

1. For each transformation, transfer $20 \mu \mathrm{g}$ of DNA to the bottom of a sterile $50 \mathrm{ml}$ Falcon tube. Note: Use $20 \mu \mathrm{g}$ DNA in a volume not greater than 30-50 $\mu$.

\section{STEPS 2-6 ARE TIME SENSITIVE}

2. Add $300 \mu$ l of protoplast suspension (from Step C11) and $300 \mu$ l of sterile PEG-MCT solution to the DNA and mix by gently tapping the tube.

3. Incubate the mixture in a water bath at $45^{\circ} \mathrm{C}$ for $5 \mathrm{~min}$, followed by $5 \mathrm{~min}$ incubation at room temperature. Meanwhile melt PRMT medium using a microwave. Keep the melted PRMT in a water bath at $45^{\circ} \mathrm{C}$.

4. Add $300 \mu \mathrm{l}$ PW solution to the "protoplast-PEG-DNA suspension" five times, with the interval of 1 min between each dilution.

5. Now add $1 \mathrm{ml} \mathrm{PW}$ solution five times with the interval of $1 \mathrm{~min}$ between each dilution.

6. Centrifuge the transformed protoplasts for $3 \mathrm{~min}$ at $200 \times \mathrm{g}$. Carefully decant the supernatant using a pipette. At this point, the protoplast pellet may not be visible, so leave a little amount ( $300 \mu \mathrm{l})$ of supernatant back while pipetting.

7. Resuspend the protoplasts in $500 \mu \mathrm{l} \mathrm{PW}$ solution.

8. Add $10 \mathrm{mM} \mathrm{CaCl} 2$ to the warm PRMT medium (maintained at $45^{\circ} \mathrm{C}$ ). Now add $2.5 \mathrm{ml}$ of this $\mathrm{CaCl}_{2}$-PRMT mixture to the protoplast suspension and tap the Falcon tube to mix gently.

9. Distribute $1 \mathrm{ml}$ of this mixture among three PRMB plates covered with single sterile cellophane disc.

Note: Slowly distribute the protoplast suspension on PRMT plate, while simultaneously and 
gently spreading the mixture with your pipette tip as you proceed. This assures a uniform distribution and avoids the dome shaped gel blotch on the plate (cut the end of the 1,000 $\mu \mathrm{ltip}$ with a heated scalpel for this step).

10. Let the protoplasts recover overnight in the dark at $25^{\circ} \mathrm{C}$.

Note: To mimic dark conditions, cover each plate with aluminum foil.

11. Incubate the plates in continuous light at $25^{\circ} \mathrm{C}$ for 5 days.

12. Transfer the cellophane discs with protoplast containing PRMT-layer onto antibiotic containing BCD plates. Cultivate the moss under standard growth conditions ( $16 \mathrm{~h}$ day $/ 8 \mathrm{~h}$ night cycle) at $25^{\circ} \mathrm{C}$ and proceed with the selection of positive transformants.

\section{Data analysis}

\section{Results}

Estimated number of protoplasts in $3 \mathrm{ml}$ of PW solution:

Protoplast on Grid 1 and Grid 2 and their average

$\frac{\text { Grid } 1+\text { Grid } 2}{2}=\frac{41+78}{2}=59.5$

Protoplasts on grid area $\times 10^{4} \times$ total volume in $\mathrm{ml}=$ number of protoplasts

$59.5 \times 10^{4} \times 3=178.5 \times 10^{4}$ or $\mathbf{1 . 7 9} \times 10^{6}$ protoplasts in $\mathbf{3 ~ m l}$

Final volume MMM protoplast suspension:

$\frac{\text { number of protoplsts }}{1.6 \times 10^{6}}=\frac{1.79 \times 10^{6}}{1.6 \times 10^{6}}=1.118 \mathrm{ml}$

\section{Selection procedure to obtain stable moss lines}

1. After 2 weeks on antibiotic containing BCD plates, transfer the cellophane disc with recovered transformants to fresh antibiotic containing BCD plates and incubate for another 2 weeks at $25^{\circ} \mathrm{C}$ under standard growth conditions.

2. Transfer each colony to antibiotic free BCD plates (overlaid with single sterile cellophane). Incubate the plates at $25^{\circ} \mathrm{C}$ under standard growth conditions for 10 days.

Note: Transfer each colony individually on the BCD plate to avoid getting chimeric colony. Sterilize the forcep with $70 \%$ ethanol and fire each time after transfer.

3. After 10 days of incubation on selection free plates, transfer a small part of each protonemal colony to BCD plate with appropriate antibiotic. Incubate the plates for 10 days at $25^{\circ} \mathrm{C}$ under standard growth conditions. Only the stable transformants grow on selection plates.

Note: Transferred protonema should only be collected from the growing end of each colony. Avoid transferring the whole colony or gametophores.

4. After 10 days of incubation on selection plates, transfer the cellophane on antibiotic free 
selection plate and let grow for a week before individually transferring them to fresh BCD plates overlaid with cellophane.

5. Verify the transformants using genotype sequence verification, metabolic profiling, or proteomics or phenomics etc.

\section{Recipes}

1. $8.5 \%(w / v)$ Mannitol (Prepare in advance)

a. Prepare $500 \mathrm{ml} 8.5 \%(\mathrm{w} / \mathrm{v})$ mannitol solution by adding $91.08 \mathrm{~g}$ of D-mannitol to $400 \mathrm{ml}$ of demineralized water

b. After dissolving, add demineralized water to make the volume up to $500 \mathrm{ml}$ and autoclave

2. $1 \mathrm{M} \mathrm{CaCl}_{2}$ (prepare in advance)

a. Prepare $500 \mathrm{ml}$ of $1 \mathrm{M} \mathrm{CaCl}_{2} \cdot 2 \mathrm{H}_{2} \mathrm{O}$ by adding $73.51 \mathrm{~g}$ of $\mathrm{CaCl}_{2}$ to $300 \mathrm{ml}$ of demineralized water

b. After dissolving, add demineralized water to make up the volume to $500 \mathrm{ml}$

c. Do not autoclave, instead filter sterilize prior to use

3. $2 \mathrm{M} \mathrm{KOH}$ (prepare in advance)

a. Prepare $100 \mathrm{ml}$ of $2 \mathrm{M} \mathrm{KOH}$ by adding $11.2 \mathrm{~g}$ of $\mathrm{KOH}$ to $50 \mathrm{ml}$ of demineralized water

b. After complete dissolution of salt, add demineralized water to make up the volume to 100 $\mathrm{ml}$ and autoclave

4. $0.2 \mathrm{M}$ MES pH 5.8 (prepare in advance)

Storage at room temperature

a. Prepare $100 \mathrm{ml}$ of $0.2 \mathrm{M} \mathrm{2-(N-morpholino)} \mathrm{ethylanesulfonic} \mathrm{acid} \mathrm{(MES)} \mathrm{by} \mathrm{adding} 3.90 \mathrm{~g}$ of MES hydrate to approx. $40 \mathrm{ml}$ of demineralized water, dissolve completely on magnetic stirrer

b. Bring the $\mathrm{pH}$ to 5.8 using $2 \mathrm{M} \mathrm{KOH}$

c. Once the $\mathrm{pH}$ is stable, add demineralized water to make the volume to $100 \mathrm{ml}$

5. Protoplast media (PM) (prepared in advance)

Storage at room temperature

a. Prepare $100 \mathrm{ml}$ of PM by adding $10 \mathrm{ml}$ of $0.2 \mathrm{M} \mathrm{MES} \mathrm{(pH} \mathrm{5.8)} \mathrm{and} 1 \mathrm{ml}$ of $1 \mathrm{M} \mathrm{CaCl}_{2}$ to 89 $\mathrm{ml}$ of $8.5 \%$ mannitol solution

b. The working concentration of MES (pH 5.8) in $\mathrm{PM}$ is $20 \mathrm{mM}$ and of $\mathrm{CaCl}_{2}$ is $10 \mathrm{mM}$

c. Filter sterilize the media

6. Protoplast wash solution (PW) (prepare in advance)

Storage at room temperature

a. Prepare $100 \mathrm{ml}$ of PW by adding $2 \mathrm{ml}$ of $0.2 \mathrm{M} \mathrm{MES}(\mathrm{pH} 5.8)$ and $1 \mathrm{ml}$ of $1 \mathrm{M} \mathrm{CaCl}_{2}$ to 97 $\mathrm{ml}$ of $8.5 \%$ mannitol

b. The working concentration of MES ( $\mathrm{pH} 5.8$ ) in $\mathrm{PW}$ is $4 \mathrm{mM}$ and of $\mathrm{CaCl}_{2}$ is $10 \mathrm{mM}$

c. Filter sterilize the media 
7. $0.4 \mathrm{M}$ Tris- $\mathrm{Cl} \mathrm{pH} 8.0$ (prepare in advance)

a. Prepare $100 \mathrm{ml}$ of $0.4 \mathrm{M}$ Tris- $\mathrm{Cl}$ by adding $4.84 \mathrm{~g}$ of Tris base to $70 \mathrm{ml}$ of demineralized water

b. When dissolved, adjust $\mathrm{pH}$ to 8.0 with $2 \mathrm{M} \mathrm{HCl}$ and add demineralized water to make the volume up to $100 \mathrm{ml}$

8. PEG-MCT (prepare fresh)

a. Prepare $5 \mathrm{ml}$ of PEG-MCT by adding $118 \mathrm{mg}$ of $\mathrm{Ca}\left(\mathrm{NO}_{3}\right)_{2} \cdot 4 \mathrm{H}_{2} \mathrm{O}$ and $125 \mu \mathrm{l} 0.4 \mathrm{M} \mathrm{Tris-Cl}$ (pH 8.0) to $5 \mathrm{ml}$ of $8.5 \%$ mannitol solution and dissolve Note: Prepare $300 \mu$ I PEG-MCT solution per transformation.

b. Add $2 \mathrm{~g}$ of polyethylene glycol (PEG, MW 6000) and mix well

c. Keep the solution on a rocker for at least $2 \mathrm{~h}$ to completely dissolve the PEG and avoid recrystallization

d. Filter sterilize the PEG-MCT solution after the PEG is dissolved

Note: Here, PEG stands for polyethylene glycol and MCT stands for Mannitol+Calcium nitrate+Tris-Cl (salts used to prepare PEG solution).

9. $1 \mathrm{M} \mathrm{MgCl}_{2}$ (prepare in advance)

a. Prepare $100 \mathrm{ml}$ of $1 \mathrm{M} \mathrm{MgCl}_{2}$ by adding $9.52 \mathrm{~g}$ of $\mathrm{MgCl}_{2}$ salt to $80 \mathrm{ml}$ of demineralized water

b. After dissolving, add demineralized water to make the volume up to $100 \mathrm{ml}$ and autoclave

10. MMM solution (prepare Fresh)

a. Prepare $10 \mathrm{ml}$ of MMM solution by adding $150 \mu \mathrm{l}$ of $1 \mathrm{M} \mathrm{MgCl}_{2}$ and $100 \mu \mathrm{l}$ of $0.2 \mathrm{M} \mathrm{MES}$ to $10 \mathrm{ml}$ of $8.5 \%$ mannitol solution in demineralized water. This is sufficient for $10-15$ transformations

b. Filter sterilize prior to use

Note: Here, $M M M$ stands for Mannitol $+\mathrm{MgCl}_{2}+\mathrm{MES} ; \mathrm{PRMB}$ stands for Protoplast Regeneration Medium Base layer; PRMT stands for Protoplast Regeneration Medium Top layer.

11. PRMB media (prepare in advance)

a. Prepare BCD media with $6 \%(\mathrm{w} / \mathrm{v})$ mannitol and $0.7 \%(\mathrm{w} / \mathrm{v})$ Agar in demineralized water, followed by autoclavation

b. Once slightly cooled, add a final concentration of $10 \mathrm{mM} \mathrm{CaCl}_{2}$ before pouring to the Petridishes. When solidified, overlay the medium with a sterile cellophane disk

c. Prepare 3 Petri-dishes with PRMB medium per transformation

12. PRMT media (prepare in advance)

a. Prepare $200 \mathrm{ml}$ of BCD media with $8 \%(\mathrm{w} / \mathrm{v})$ Mannitol and $0.4 \%(\mathrm{w} / \mathrm{v})$ agar in demineralized water, followed by autoclavation

b. Once slightly cooled, aliquot $50 \mathrm{ml}$ media to four sterile $100 \mathrm{ml}$ reagent bottles inside the LAF bench

Optional: One of the aliquots can be stored in $60^{\circ} \mathrm{C}$ oven to keep warm. This media can be 
used on the same day for transformation or can be stored for max 2 weeks in melted form.

c. Aliquots can be stored at room temperature and when required can be heated prior to use (see Step D3)

Note: Heating of the media in the microwave should be carried out under the supervision of experienced person while following the safety guidelines.

13. BCD Media (prepare in advance)

a. Prepare $1 \mathrm{~L}$ of $\mathrm{BCD}$ media by mixing:

$12.5 \mathrm{mg} \mathrm{FeSO}{ }_{4} \cdot 7 \mathrm{H}_{2} \mathrm{O}$

$10 \mathrm{ml}$ "Solution B" $\left(25 \mathrm{~g} / \mathrm{L} \mathrm{MgSO}_{4} \cdot 7 \mathrm{H}_{2} \mathrm{O}\right)$

$10 \mathrm{ml}$ "Solution C" (25 g/L KH $2 \mathrm{PO}_{4}$, pH adjusted to 6.5 with $\left.4 \mathrm{M} \mathrm{KOH}\right)$

$10 \mathrm{ml}$ "Solution D" (101 g/L KNO 3 )

b. To this add $1 \mathrm{ml}$ of "Trace element solution" (614 mg H $\mathrm{mBO}_{3}, 389 \mathrm{mg} \mathrm{MnCl} 2 \cdot 4 \mathrm{H}_{2} \mathrm{O}, 110 \mathrm{mg}$ $\mathrm{AIK}\left(\mathrm{SO}_{4}\right)_{2} \cdot 12 \mathrm{H}_{2} \mathrm{O}, 55 \mathrm{mg} \mathrm{CoCl} \cdot 6 \mathrm{H}_{2} \mathrm{O}, 55 \mathrm{mg} \mathrm{CuSO}_{4} \cdot 5 \mathrm{H}_{2} \mathrm{O}, 55 \mathrm{mg} \mathrm{ZnSO}_{4} \cdot 7 \mathrm{H}_{2} \mathrm{O}, 28 \mathrm{mg} \mathrm{KBr}$, $28 \mathrm{mg} \mathrm{KI}, 28 \mathrm{mg} \mathrm{LiCl}, 28 \mathrm{mg}$ and $\mathrm{SnCl}_{2} \cdot 2 \mathrm{H}_{2} \mathrm{O}$ per liter)

14. BCD Plate (prepare in advance)

a. For every transformation, prepare 3 Petri-dishes with BCD medium containing $0.7 \%(\mathrm{w} / \mathrm{v})$ agar and the antibiotic corresponding with the selection marker used for transformation

b. Add a final concentration of $1 \mathrm{mM} \mathrm{CaCl}_{2}$ before pouring into the Petri-dishes

15. $500 \mathrm{mM}$ Ammonium tartrate (prepare in advance)

a. Prepare $100 \mathrm{ml}$ of $500 \mathrm{mM}$ of Ammonium tartrate $\left(\mathrm{C}_{4} \mathrm{H}_{12} \mathrm{~N}_{2} \mathrm{O}_{6}\right)$ by adding $9.21 \mathrm{~g}$ ammonium tartrate salt to $80 \mathrm{ml}$ of demineralized water

b. When dissolved further add water to make up the volume to $100 \mathrm{ml}$

c. Filter sterilize prior to use

\section{Acknowledgments}

The work was supported by a research grant (00022855) from Villum Fonden, as part of the VILLUM Experiment programme, and by two Erasmus+ stipends. The protocol was modified from Bach et al., 2014.

\section{Competing interests}

The authors declare that the research was conducted in the absence of any commercial or financial relationships that could be construed as a potential conflict of interest.

\section{References}

1. Abel, S. and Theologis, A. (1994). Transient transformation of Arabidopsis leaf protoplasts: a versatile experimental system to study gene expression. Plant J 5(3): 421-427. 
2. Bach, S. S., King, B. C., Zhan, X., Simonsen, H. T. and Hamberger, B. (2014). Heterologous stable expression of terpenoid biosynthetic genes using the moss Physcomitrella patens. Methods Mol Biol 1153: 257-271.

3. Chamani, E. and Tahami, S. K. (2016). Efficient protocol for protoplast isolation and plant regeneration of Fritillaria imperialis L. J Agr Sci Techy 18: 467-482.

4. Cove, D. J., Perroud, P. F., Charron, A. J., McDaniel, S. F., Khandelwal, A. and Quatrano, R. S. (2009). Chemical and UV mutagenesis of spores and protonemal tissue from the moss Physcomitrella patens. Cold Spring Harb Protoc 2009(2): pdb prot5142.

5. Fesenko, I., Seredina, A., Arapidi, G., Ptushenko, V., Urban, A., Butenko, I., Kovalchuk, S., Babalyan, K., Knyazev, A., Khazigaleeva, R., Pushkova, E., Anikanov, N., Ivanov, V. and Govorun, V. M. (2016). The Physcomitrella patens Chloroplast Proteome Changes in Response to Protoplastation. Front Plant Sci 7: 1661.

6. Kaur, N. D., Vyvadilová, M., Klíma, M. and Bechyně, M. (2018). A Simple Procedure for Mesophyll Protoplast Culture and Plant Regeneration in Brassica oleracea L. and Brassica napus L. Czech J Genet Plant Breed.

7. King, B. C., Vavitsas, K., Ikram, N. K., Schrøder, J., Scharff, L. B., Bassard, J. É., Hamberger, B., Jensen, P. E. and Simonsen, H. T. (2016). In vivo assembly of DNA-fragments in the moss, Physcomitrella patens. Sci Rep 6: 25030.

8. Priyadarshani, S., Hu, B., Li, W., Ali, H., Jia, H., Zhao, L., Ojolo, S. P., Azam, S. M., Xiong, J., Yan, M., Ur Rahman, Z., Wu, Q. and Qin, Y. (2018). Simple protoplast isolation system for gene expression and protein interaction studies in pineapple (Ananas comosus L.). Plant Methods 14: 95.

9. Raimundo, S., Sørensen, I., Tinaz, B., ritter, E., Rose, J. and Domozych, D. (2018). Isolation and manipulation of protoplasts from the unicellular green alga Penium margaritaceum. Plant Methods 14: 2-18.

10. Reski, R., Bae, H. and Simonsen, H. T. (2018). Physcomitrella patens, a versatile synthetic biology chassis. Plant Cell Rep 37(10): 1409-1417.

11. Simonsen, H. T., Drew, D. P. and Lunde, C. (2009). Perspectives on using physcomitrella patens as an alternative production platform for thapsigargin and other terpenoid drug candidates. Perspect Medicin Chem 3: 1-6.

12. Yoo, S. D., Cho, Y. H. and Sheen, J. (2007). Arabidopsis mesophyll protoplasts: a versatile cell system for transient gene expression analysis. Nat Protoc 2(7): 1565-1572. 